\title{
Proloog
}

\section{Over kwaliteit gesproken}

Prof. Dr. P.S.H. Leeflang

\section{Inleiding op het thema 'lkwaliteit van dienstverlening'}

In de afgelopen decennia hebben talrijke onderwerpen veel aandacht gekregen in de praktijk van het management en in de managementliteratuur. In navolging van de levenscycli van produkten en merken kunnen we over 'levenscycli van onderwerpen' spreken. Zo hebben we een grote, vaak tijdgebonden, aandacht kunnen waarnemen voor onderwerpen als 'strategie', 'strategische planning', 'agency-theorie en transactiekosten', 'concurrentie en concurrentie-analyse', 'netwerken', 'strategische allianties', 'industriepolitiek', 'fusies, overnames' (de markt voor vennootschappelijk bestuur),' 'internationalisering', 'kritische succesfactoren', enzovoort. Deze en andere onderwerpen hebben in de loop der tijden uitvoerig aandacht gekregen in de literatuur, onder meer ook in het MAB. Nadat het onderwerp vaak door middel van een baanbrekend artikel, is geïntroduceerd vindt een diffusie van aandacht onder beroepsbeoefenaren en theoretici plaats. Dit kan zich uiten in een lawine van artikelen, boeken, proefschriften, andere diepgaande onderzoeken, geschriften, seminars, congressen en wat dies meer zij. Na enige tijd verflauwt de aandacht, omdat andere 'nieuwe produkten' om aandacht vragen, het onderwerp toch niet zo veelbelovend is als in eerste instantie leek of omdat het onderwerp gemeengoed is geworden. Ook kan een 'revival' optreden, het onderwerp komt wederom in de belangstelling te staan. Zo hebben recente economische ontwikkelingen ervoor gezorgd dat een onderwerp als industriepolitiek weer in het centrum van de belangstelling staat. ${ }^{2}$ Vaak ook dient een onderwerp verder te rijpen voordat het opnieuw in de levenscyclus gebracht wordt ('recycling'). Sommige levenscycli hebben een lange levensduur: de onderwerpen blijven in de belangstelling staan. Andere onderwerpen zijn sterk aan mode onderhevig, hebben een levensduur van enkele jaren of zelfs maanden en blijken vaak niet bij te dragen tot begrip, inzicht of resultaat. Dit zijn vaak onderwerpen die betrekking hebben op deelspecialismen en we zouden ze als 'theorieën van de maand' kunnen bestempelen. Het onderwerp dat in dit themanummer centraal staat, te weten 'kwaliteit van dienstverlening' kan gaan behoren tot die onderwerpen die een lange en rendabele levensweg tegemoet kunnen gaan zien. Om die reden en vanwege het belang van dit onderwerp voor de beroepsoefening van veel lezers van het $M A B$, heeft de redactie besloten om aan de kwaliteit van dienstverlening een themanummer te wijden.

In deze inleiding op dit themanummer zullen we allereerst stil staan bij de aandacht voor en het belang van dit onderwerp. Vervolgens zullen we de samenhang tussen de diverse artikelen schetsen en daarmee de weg 'door dit themanummer' banen.

\section{Kwaliteit en kwaliteit van dienstverlening}

De aandacht voor kwaliteit is niet bepaald nieuw te noemen. Wat wel nieuw is, is de richting waarin de aandacht zich ontwikkelt en waarop deze aandacht zich richt. Zoals in het artikel van

Prof. Dr. P.S.H. Leeflang is als hoogleraar Marktkunde en Marktonderzoek verbonden aan de Faculteit der Economische Wetenschappen (FEW) van de Rijksuniversiteit Groningen ( $R \cup G$ ). 


\section{MAB}

Reuyl en Willenborg (1993) ter sprake komt, wordt in deze tijd aan het onderwerp 'kwaliteit' de hoogste prioriteit gegeven door managers. Dat het hier niet om een mode-onderwerp gaat c.q. om een theorie van de maand moge duidelijk zijn op grond van de aandacht die dit onderwerp al decennia lang ondervindt. ${ }^{3}$ Zo kregen Van Ettinger en Sittig (1961) meer dan dertig jaar geleden veel aandacht voor hun 'kwaliteitscircuit'. Het ontwerpen van kwaliteit werd door hen, zoals elk ontwerpproces, als een itererend proces gezien waarbij in elke ontwerpfase teruggekoppeld moest worden naar de eisen en wensen van de markt. Ook in de produktie-managementliteratuur wordt al enkele decennia lang aandacht aan 'kwaliteit' gegeven. ${ }^{4}$

De 'revival' voor het onderwerp 'kwaliteit' wordt gevoed door de, meer recente, aandacht voor de kwaliteit van diensten. Deze aandacht is zo groot dat Steenkamp (1993) in dit verband over een kwaliteitsrevolutie spreekt. Met name in de marketingliteratuur staat dit onderwerp sterk in de belangstelling en bevindt deze aandacht zich nog steeds in de groeifase van de levenscyclus van dit onderwerp. ${ }^{5}$

Ook onder de producenten van diensten is een toenemende aandacht voor de kwaliteit van hun dienstverlening te bespeuren. Onder reclamemakers en marktonderzoekers wordt driftig gediscussieerd over ISO-normen voor respectievelijk reclamebureaus en marktonderzoekbureaus. ${ }^{6}$

Zoals, naar ik aanneem, bekend is onder de lezers van het $M A B$, heeft het NIvRA in november 1992 een beleidsprogramma voor de jaren 1993-1998 geformuleerd onder de titel 'kwaliteit en samenwerking'. Ook in deze nota is ruimschoots aandacht gegeven aan het begrip kwaliteit en wordt aandacht besteed aan de vraag in hoeverre er kwaliteitsverschillen tussen controlediensten mogen bestaan en er kwaliteitscontrole (bij de overgang van opdrachten) zou moeten plaatsvinden.? Dat een discussie over deze onderwerpen nog niet tot eensluidende conclusies geleid heeft, mag duidelijk worden na lezing van de reacties op het artikel van Blokdijk (1993a) door Dassen en Maijoor (1993) alsmede uit de reactie van Blokdijk (1993b) op de genoemde reactie.
Dat er nog groei mogelijk is voor de aandacht van de kwaliteit van dienstverlening door accountants kunnen we adstrueren aan de hand van enkele gegevens uit ons onderzoek naar de markt voor accountantsdiensten. Zo worden door aanbieders van accountantsdiensten criteria als 'geven van advies op eigen initiatief', 'meedenken met de dienst' en 'prijs per opdracht' belangrijker geacht dan 'kwaliteit' om zich te onderscheiden van collega-kantoren. ${ }^{8}$ Bij het beoordelen, van accountantskantoren door cliënten neemt het criterium 'kwaliteit' eerst de zesde plaats in. ${ }^{9}$ Daarbij moet wel worden aangetekend dat kwaliteit een multi-interpretabel concept is. Zo varieert de betekenis die door cliënten aan 'kwaliteit' wordt toegekend van 'het niveau van rapportage door de aanbieder' tot 'het ongevraagd geven van adviezen van uiteenlopende aard'. Wat minder ondubbelzinnig is, is het gegeven dat 'ontevredenheid over kwaliteit', één van de belangrijkste redenen is om van accountant te wisselen.

Dat kwaliteit niet bij alle cliënten het belangrijkste criterium is om een accountant op te beoordelen, wordt bevestigd door de (conjuncte) analyse die wij uitgevoerd hebben met behulp van gegevens van cliënten van accountantsdiensten. Uit deze analyse ontstond duidelijk een beeld van een segment gebruikers van accountantsdiensten die kwaliteit boven alle andere attributen prefereert. Bij andere segmenten prevaleren andere criteria. De belangstelling voor het onderwerp 'kwaliteit van dienstverlening' kunnen we ten slotte adstrueren door te wijzen op de ontwikkeling van programma's in dienstverlenende organisaties om zoveel mogelijk medewerkers te doordringen van het consument-gerichte denken. Enkele voorbeelden zijn de ANWB met zijn KANS-project (KANS: Kwaliteit Als Nieuwe Stimulans), KLM met het KICK-project (KLM Is Continue Kwaliteit), HEMA ('Service tot in de puntjes'), Volvo ('ledereen heeft een klant') en Philips ('Company wide quality improvement').

\section{Aspecten van de kwaliteit van dienstverlening}

In deze paragraaf zullen we op enkele aspecten 


\section{MAB}

van de kwaliteit van dienstverlening ingaan die in de artikelen van dit themanummer aandacht krijgen.

Kwaliteit is een begrip dat gerelateerd is aan de specifieke karakteristieken van een produkt of dienst. Deze karakteristieken worden ook wel attributen genoemd. Attributen kunnen worden geclassificeerd in 'search', 'experience' en 'credence' attributen. 'Search' attributen zijn eigenschappen van het produkt/dienst die voor de koop/aanschaf kunnen worden vastgesteld.

'Experience' attributen worden na aankoop, in het gebruik waargenomen en 'credence' attributen kunnen zich eerst na enige tijd openbaren. Bij diensten, en zeker bij accountantsdiensten, spelen 'credence' attributen een belangrijke rol. Door hun aard zullen de 'credence' attributen moeilijk door cliënten te beoordelen zijn. Cliënten kunnen en zullen evenwel bij het beoordelen van de kwaliteit van diensten steun zoeken bij andere signalen. In de economische theorie hebben de marktsignalen reclame en prijs veel aandacht gekregen. In zijn bijdrage gaat Steenkamp (1993) na of en zo ja in hoeverre consumenten erop kunnen vertrouwen dat deze marktsignalen betrouwbare kwaliteitsinformatie geven.

Uit het vorenstaande mag blijken hoe moeilijk het is om de kwaliteit van diensten te kunnen meten. Willenborg en Reuyl (1993) gaan hierop dieper in, en geven bovendien aan hoe kwaliteit 'gemanaged' kan worden in organisaties. Daarbij komen we op het onderwerp 'kwaliteitsmanagement. In hun artikel besteden zij aandacht aan de factoren die van invloed kunnen zijn op het succes en falen van kwaliteitsprogramma's.

Roest en Verhallen (1993) gaan op dit laatste verder in wanneer zij hun stappenplan ter effectuering van een kwaliteitsprogramma uiteen zetten. Ook bij hen staat, evenals bij Reuyl en Willenborg (1993), de vraag centraal hoe interne kwaliteitsprogramma's kunnen aansluiten bij externe kwaliteitspercepties van afnemers. Hun ABCDEstappenplan geeft goede mogelijkheden om kwaliteitsprogramma's bij de aanbieders van accountantsdiensten te implementeren.
Zoals hiervoor reeds werd aangegeven, is het beoordelen van de kwaliteit van diensten geen eenvoudige zaak. In de theorie en in de praktijk van de dienstverlening zijn evenwel enige procedures ontwikkeld om de kwaliteit van diensten te meten. In het artikel van Vriens en Boerkamp (1993) wordt een (beknopt) overzicht gegeven van de literatuur op dit terrein. Tevens bieden de auteurs een methodologie aan die gebruikt kan worden voor het meten van de kwaliteit van diensten. Zij passen in dit verband conjuncte analyse als methodiek toe op de dienstverlening van apotheken. Tevens geven zij aan hoe deze methodiek, in principe, vertaald kan worden in managementbeslissingen. Gegeven de beperkte waarnemingen waarover de auteurs beschikken mogen aan de conclusies van hun studie geen generalisaties verbonden worden. Wel illustreert het artikel hoe conjuncte analyse gebruikt zou kunnen worden.

Graag hadden wij in dit themanummer enkele bijdragen willen opnemen van accountants over de kwaliteit van hun dienstverlening. Helaas zijn deze artikelen 'te vroeg' verschenen (Blokdijk, 1993a, 1993b; Dassen, Maijoor, 1993) of moeten zij nog verschijnen. We prijzen ons echter gelukkig met de bijdragen van Schilder, Severeyns (1993) en (opnieuw!) Blokdijk (1993c) die dit thema afsluiten. Evenals bij reclamemakers en marktonderzoekers het geval is, wordt door accountants ook gedacht aan het certificeren van diensten aan de hand van ISO-normen. Schilder en Severeyns (1993) maken melding van één accountantskantoor dat reeds op deze wijze gecertificeerd is. Schilder en Severeyns (1993) hebben de ISO-normen als het ware vertaald naar de kwaliteitsnormen die bij accountants bekend zijn en worden toegepast. De auteurs komen tot de conclusie dat de combinatie van wettelijke bepalingen, GBR en richtlijnen adequaat zijn waar het 'het produktieproces' van accountantsdiensten betreft. Minder sterk, aldus Schilder en Severeyns (1993), is de regelgeving inzake de commerciële aspecten van 'het beroep', omdat zaken als verkoop, inkoop, nazorg en kwaliteitskosten relatief weinig aandacht verkrijgen. Wellicht kan de inhoud van dit themanummer bijdragen aan normering en met 


\section{MAB}

name verhoging van de kwaliteit van deze dienstverlening.

Ten slotte: we hopen met dit themanummer de lezers van het $M A B$ een dienst te hebben bewezen die kwaliteit bezit.

\section{Literatuur}

Blokdijk, J.H. (1993a), 'Invloeden van de Markt op de Kwaliteit van Accountantscontrole', MAB, jrg. 67, pp. 141-147.

Blokdijk, J.H. (1993b), 'Kwaliteitsverschillen tussen Accountants zijn bij op Derden gerichte Opdrachten Ongewenst', $M A B$, jrg. 67, pp. 482-485.

Blokdijk, J.H. (1993c), 'Epiloog: Kwaliteit van diensten: lessen voor accountants?', $M A B$, jrg. 67, pp. 624-626

Boskma, K. (1988), Produktie en Logistiek, 3e druk, WoltersNoordhof, Groningen.

Bouma, J.L. (1990), 'De Markt voor Vennootschappelijk Bestuur', MAB, jrg. 64, pp. 559-568.

Dassen, R.J.M. en S.J. Maijoor (1993), 'Invioeden van de Markt op de Kwaliteit van Accountants', MAB, jrg. 67, pp. $478-481$

Douma, S.W. (1993), 'Industriepolitiek', MAB, jrg. 67 pp. $437-439$

Ettinger. J. van en J. Sittig (1961), Meer door Kwaliteit, Bouwcentrum, Rotterdam.

Kunst, P. en J.G.A.M. Lemmink (red.) (1992), Quality Management in Services. Van Gorcum, Assen/Maastricht.

Leeflang, P.S.H., S. Alkema, E. Rosbergen, M. Vriens (1992), 'De Markt voor Accountantsdiensten in Nederland (2), de aanbodzijde, $M A B$, jrg. 66, pp. 153-161.
Lemmink, J.G.A.M. (1991), Kwaliteitsconcurrentie tussen Ondernemingen, Proefschrift ter verkrijging van de graad van doctor aan de Rijksuniversiteit Limburg.

Reuyl, J.C. en G.B.W. Willenborg (1993), 'Aspecten van Kwaliteit en Kwaliteitsmanagement in Service-organisaties', $M A B$, jrg. 67, pp. 566-580.

Roest, H.C.A. en Th.M.M. Verhallen (1993), 'Een Stappenplan ter Effectuering van Kwaliteit als Commerciële Strategie', $M A B$, jrg. 67, pp. 581-588.

Schilder, A. en P.J.J. Severeyns (1993), 'NEN-ISO-Normen en Kwaliteit van Accountantswerk', MAB, jrg. 67, pp. 613-623

Steenkamp, J.E.B.M. (1989), Product Quality, Books International, Vernon (VA).

Steenkamp, J.E.B.M. (1993), 'Kwaliteit van Diensten: Enige Inzichten uit de Economische Theorie', MAB, jrg. 67, pp. 589-598.

Vriens, M. en E.J.C. Boerkamp (1993), 'Het Optimaliseren van Dienstverlening', MAB, jrg. 67, pp. 599-612.

Vriens, M.. P.S.H. Leeflang, E. Rosbergen en T. Wilms (1992), 'De Markt voor Accountantsdiensten in Nederland (3), de vraagzijde, $M A B$, jrg. 66, pp. 231-246.

\section{Noten}

1 Zie Bouma (1990).

2 Zie Douma (1993)

3 Zie Steenkamp (1989).

4 Zie Boskma (1988).

5 Zie bijvoorbeeld Lemmink (1991); Kunst, Lemmink (1992).

6 Zie bijvoorbeeld Nieuwstribune, 7 oktober 1993, pp. 34-35.

7 Zie Blokdijk (1993b).

8 Zie Leeflang. Alkema, Rosbergen, Vriens (1992, p. 138).

9 Zie Vriens, Leeflang, Rosbergen, Wilms (1992, p. 231). 